\author{
JERZY NikitorowicZ \\ UNIWERSYTETU W BIAEYMSTOKU \\ E-MAIL: JERZYNIKI@WP.PL
}

\title{
PROBLEMY TOŻSAMOŚCIOWE OBYWATELI PAŃSTW POWSTAŁYCH PO UPADKU ZSRR
}

Z edukacyjnego punktu widzenia wartością jest, aby transkulturowe procesy na pograniczach polityczno-kulturowych dokonywały się na gruncie wartości demokratycznych i prowadziły ku społeczeństwom wielokulturowym. Jednakże w ostatnim okresie zauważalna jest coraz wyraźniej zmniejszająca się wiara w demokrację, w poczucie europejskiej i planetarnej solidarności, we wspólne dobro cywilizacyjne kształtowane od wieków na bazie judaizmu, chrześcijaństwa, filozofii greckiej i prawa rzymskiego. Uważam, że w większości państw powstałych po upadku ZSRR nie nastąpiło dostateczne przygotowanie świadomościowe, społeczno-polityczne i ekonomiczne do rozszerzającego się dynamicznie wachlarza wielokulturowości. Poza tym, przestrzeń wielokulturowości rozbudowuje się szybciej niż się spodziewano. Równocześnie $\mathrm{z}$ tymi procesami rozbudowywania wielokulturowości mają miejsce inne zjawiska i procesy niesprzyjające procesom integracji. To powoduje, moim zdaniem, wzrost zachowań separatystycznych, fundamentalizm religijny i narodowy, który powstał i rozwija się między innymi jako reakcja na procesy globalizacji, kryzys ekonomiczny, zwiększenie mobilności i migracji.

Większość narodów, będąc pod hegemonią ZSRR, odnosiło się do siebie życzliwie, wyrażało szacunek, solidarność, budowało więzi, kształtowało zaufanie. Był to z pewnością wyraz i potrzeba wspólnotowości w kontekście wspólnego wroga zawłaszczającego wolność i autonomię narodową. Idea solidarności wyraźnie osłabła, gdy poszczególne narody zaczęły się wyzwalać i samodzielnie kształtować i realizować własną tożsamość narodową. Podjęto nawet próby kształtowania tożsamości narodowej w opozycji do 
innego narodu lub narodów sięgając do historycznych mitów, narosłych uprzedzeń, wskazując i analizując doznane krzywdy. Zaczęła pojawiać się niechęć, zła pamięć, wzajemne oskarżenia, odnawianie stereotypów. W efekcie, zamiast niwelowania narosłych historycznie stereotypów i uprzedzeń, pojawiło się więcej wrogów, lęku i niezrozumienia. Jednocześnie tożsamość osobowa i społeczno-kulturowa (indywidualna i grupowa) stawała się bogatsza, bardziej świadoma, rozbudowana, bardziej uwidoczniły się jej wymiary, nastąpiła rewitalizacja, nadanie znaczenia i wartości wielu elementom kształtującym ją w wielokulturowym świecie.

Prowadząc od wielu lat badania na pograniczu polsko-litewsko-białoruskim, a także ukraińskim [zob. Nikitorowicz 2000] zauważyłem, że pewnych zjawisk, w tym szczególnie zjawiska tożsamości, nie dostrzega się i nie analizuje, gdy nie przysparzają problemów. Zauważa się je, skupia na nich uwagę, szczególnie wówczas, gdy zatracają jasność, gubią się w warunkach zmiany, takiej na przykład jak powstawanie wolnych, niezależnych państw po rozpadzie ZSRR. Zachodzące bowiem procesy w tych krajach stawiają jednostkom, grupom i całym społeczeństwom nowe wyzwania, powodując między innymi ustawiczne pytania o to kim jestem, kim się staję, kim chciałbym być, kim warto, powinienem, wprowadzając wiele osób w stan dyskomfortu i frustracji. Coraz większej liczbie ludzi nie udaje się sprostać nowym wyzwaniom, wielu okazuje zobojętnienie, rezygnując $\mathrm{z}$ aktywności i twórczych działań, generując demony, lęki, kompleksy, wzniecając ustawicznie wojnę polsko-polską, polsko-rosyjską, polsko-niemiecką czy polsko-europejską. Barbara Skarga pisała „tożsamość jest problemem, nie mamy pewności, czy nie stanowimy w ogóle iluzji. Nie wiemy także dobrze, co to właściwie znaczy to bycie sobą, dlaczego owej sobości szukamy, czy jest ona dla nas jakąś wartością, a jeżeli tak, to dlaczego" [Skarga 1997].

Może należałoby skorzystać z propozycji Ulricha Becka, oferty nowego popkosmopolityzmu, swoistej eklektyzacji kulturowej, przynależenia do wielu kultur naraz, co może chronić nowe kultury przed ortodoksją. Pisze wskazany autor: „Kosmopolityzm uznaje, że Europejczycy mają dziś wiele różnych nakładających się tożsamości. Tożsamość narodowa, tak jak rozumiano ją w XIX wieku staje się iluzją, nawet jeśli nacjonaliści nie chcą tego przyjąć do wiadomości, że Turcy w Niemczech nie są Turkami z Turcji, Polacy w Anglii nie będą tacy jak w Polsce" [Beck 2007].

Powyższa recepta eklektyzacji kulturowej wydaje się szczególnie istotna w kontekście częstego prezentowania w państwach powstałych po upadku 
ZSRR, szczególnie w Rosji, wizerunku wroga, szerzenia nacjonalizmu i szowinizmu w procesie kreowania tożsamości narodowej. Do tego dochodzi przekonanie większości Rosjan o wyjątkowości cywilizacyjnej, przekonanie, że „rozumem Rosji się nie pojmie” (fraza z wiersza Fiodora Tiutczewa cieszy się obecnie popularnością w dyskursie społecznym). Idee nacjonalistyczne zdobywają uznanie, rozbudowuje się ksenofobiczne nastroje między innymi poprzez coroczny masowy „Ruskij marsz” 4 listopada (Dzień Jedności Narodowej) z hasłami: „Biej żydow, spasaj Rossiju”, „Rossija tolko dla ruskich”, „Precz z naszej ziemi”. Elity kulturalne w Rosji po upadku ZSRR próbują odnaleźć się $\mathrm{w}$ trudnym procesie poszukiwania idei integrującej, jednak zmierzają w kierunku fundamentalizmu, ku nacjonalizmowi mocarstwowemu i ku nacjonalizmowi etnicznemu. Jak wskazuje Victoria Dunajeva [2012: 194] w ciągu ostatniej dekady (2001-2011) prawie wszystkie ośrodki badań społecznych w Rosji odnotowały wzrost nastrojów nacjonalistycznych i antymigracyjnych. Większość Rosjan mobilizuje ich wspólny wróg, głównie imigranci. Dla współczesnej rosyjskiej młodzieży nacjonalizm stał się wyraźną ideą odrodzenia imperium czy mesjanizmu cerkiewno-rosyjskiego. W wielu periodykach narodowo-patriotycznych używa się prostego języka i protestuje przeciwko okupacji rosyjskiej ziemi przez imigrantów. Walerij Sołowiej, ekspert Fundacji M.Gorbaczowa w komentarzu do pisma „Nowe Państwo” stwierdził, że ZSRR rozpadł się głównie z powodu braku silnego kręgosłupa, na którym wszystko się trzyma - czyli narodu. Rosyjski nacjonalizm jest zdolny do tego, żeby stać się ideologią nowego państwa rosyjskiego, gdyż obecny model państwowy nie przetrwa. Albo Rosja stanie się państwem rosyjskiego narodu i przetrwa, albo nastąpi jej upadek [Dunajeva 2012: 197-198].

W wielu krajach powstałych po upadku ZSRR podejmuje się próby przezwyciężenia poważnych dylematów dziedzictwa radzieckiego, między innymi problemów związanych z rywalizacją wyborczą, nastrojami separatystycznymi, rozszerzaniem się wszechobecnej korupcji, wzajemnym oskarżaniem się w debatach tożsamościowych. Miałem możliwość przebywania jeszcze jako student, między innymi w Bucharze, Samarkandzie, Duszanbe i obserwowania nieprzystawalności kultur, pozorów integracji, życia obok siebie, a w ostatnich latach podejmowania rozmów na konferencjach w Petersburgu, Moskwie czy Kijowie w kontekście dominacji systemu totalitarnego nad kulturami narodów podporządkowanych. Sowieci ustawicznie wyzwalali ruchy nacjonalistyczne chcąc urzeczywistnić nacjonali- 
styczną zasadę - jeden naród, jedno państwo. W efekcie można wyraźnie zauważyć kształtowanie się tożsamości kontekstualnej, gdzie sytuacje, określone warunki i okoliczności decydowały o określaniu tożsamościowym. Prezentacje i zaangażowanie tożsamościowe często było uzależnione od określonych potrzeb i możliwości realizacji kariery. Tak więc nie przekraczali wewnętrznie odziedziczonej tożsamości, nie dokonywali interioryzacji i na jej bazie eksterioryzacji, nie poszerzali i nie konstruowali tożsamości w kontekście nowych warunków, a schizofrenicznie funkcjonowali.

W połowie XIX wieku, gdy Rosjanie zaczęli podbój Azji Środkowej, nikt nie myślał kategoriami narodowymi. Żyły obok siebie ludność turecka i perska, dwujęzyczność była na porządku dziennym, a ważniejsze dla poczucia solidarności i szacunku wzajemnego, lojalności grupowej była wyznawana religia, więzy rodowe (u koczowników), sposób zarabiania na życie, styl życia i pracy (u ludności osiadłej). Formy identyfikacji były jasne, związane z samoidentyfikacją pokoleniową, a nie identyfikacją i kategoryzacją dokonaną przez innych. Dla każdego z pięciu narodów (Turkmenów, Kazachów, Kirgizów, Uzbeków i Tadżyków) radzieccy uczeni opracowali skodyfikowane wersje języków narodowych. Słownictwo dobierano tak, aby uwypuklić różnice pomiędzy poszczególnymi dialektami. Stworzono narodowe narracje na temat historii, wykazując, że dany naród od setek lat zamieszkiwał określony obszar. Utworzono lokalną administrację, w której rdzenna ludność miała administrować, co powodowało, że zmieniali swoją deklarowaną narodowość w zależności od przemian administracyjno-terytorialnych. Jak pisze Ludwika Włodek „działacz komunistyczny, który zaczynał swoją przygodę z polityką jeszcze w nacjonalistycznej turkiestańskiej Ałasz-Ordzie, Turar Ryskułow, w dobie rewolucji określał się jako Kirgiz, dla pokazania swej solidarności ze wszystkimi koczowniczymi ludami stepu, potem nazywał siebie Turkiestańczykiem, by wreszcie, po 1924 roku, stać się Kazachem. Z kolei wielu Tadżyków z Samarkandy i Buchary w 1924 roku podawało się za Uzbeków. Część z nich, jak Abdullo Rachimbajew, zmieniała narodowość na tadżycką dopiero w 1929 roku, gdy wraz z utworzeniem się tadżyckiej republiki związkowej pojawiła się możliwość kariery w administracji dla przedstawicieli tej narodowości” [Włodek 2014: 50]. Można powiedzieć, że unikali napięć, dostosowywali się do sytuacji, gdyż niepewnych ideologicznie czystki stalinowskie pozbawiały życia. Byli często zmuszani deklarować w oficjalnych dokumentach inną narodowość niż ta, do jakiej się poczuwali.

Nie udało się urzeczywistnić nacjonalistycznej zasady; jeden naród - jedno państwo. W każdej republice znalazła się znacząca grupa Uzbeków, 
a w dwóch największych miastach Uzbekistanu (Samarkanda i Buchara) mieszka duża liczba Tadżyków. W ZSRR podziały etniczne nie miały tak wielkiego znaczenia jak po jego rozpadzie, gdyż dominowała polityka „slijania” (jeden, solidarny i światły naród radziecki). W procesie ujednolicenia kulturowego ludności ZSRR wszyscy mieli przyswoić tę samą radziecką hierarchię wartości i norm, a więc różnice narodowe miały nie mieć znaczenia. Gdy słabło imperium radzieckie następował wzrost świadomości wspólnotowej, powiązań grupowych, plemiennych. Elity każdej z republik wskazywały, że dobrze byłoby Kirgiską republikę uczynić bardziej kirgiską, Tadżykistan - bardziej tadżyckim. Po krwawych konfliktach etnicznych na terytorium Azji Środkowej problem tożsamości pozostał nierozwiązany i trwa spór o to, kto ma prawo nazywać się prawdziwym Kirgizem, Uzbekiem, Kazachem, który naród jest najstarszy, najdostojniejszy, rdzenny itp. Do powyższego problemu dołączył problem Ukrainy. Jurij Andruchowicz podczas posiedzenia Zgromadzenia parlamentarnego Rady Europy w Strasburgu 15 grudnia 2004 roku podkreślił: „Toczący się dziś na Ukrainie dramat nie mieści się w żadnym z modeli przygotowanych dla niej zawczasu przez technologów politycznych. Nie jest to wystąpienie Ukraińców ukraińskojęzycznych przeciwko Ukraińcom rosyjskojęzycznym. Nie jest to tym bardziej konflikt „proeuropejskiego" zachodu naszego kraju z „prorosyjskim” wschodem. Nie są to też porachunki klanów czy grup finansowych... Na wszystkich tych konfliktach "gra się"... to przede wszystkim uniwersalny dramat historyczny: konflikt między społeczeństwem (a przynajmniej znaczna jego częścią, tą najbardziej aktywną, świadomą i wykształconą), która chce demokracji, dobrobytu i państwa prawa a władzą, która ze wszystkich sił próbuje zachować autorytarno-neotatalitarną formę sprawowania rządów, z takim powodzeniem i cynizmem wcielaną w życie przez wszystkich dziedziców sowieckiego reżimu komunistycznego na całym postradzieckim terytorium" [Andruchowicz 2005: 9-10].

W kontekście powyższego można powiedzieć, że jeżeli wcześniej tożsamość nie była wielkim obciążeniem to obecnie jest, nie tylko ze względu na tendencje nacjonalistyczne i autorytarne, ale także ze względu na fragmentaryzację, utratę, zmiany, negocjowanie itp. Rozpad ZSRR spowodował uruchomienie świadomości ku rewitalizacji tradycyjnych i nowych wartości, odwoływanie się do samoświadomości, samorealizacji i samodyscypliny, organizowanie warunków i sytuacji aby stawać częściej i bardziej zdecydowanie w wietrze myśli, jak mawiała Hannah Arendt, uczyć się ustawicznego prowadzenia dialogu wewnętrznego i zewnętrznego. 
W kontekście powyższego, między innymi wspólnych losów, doznanych krzywd i upokorzeń, historycznego dziedzictwa pogranicza kultur, zauważam wiele problemów tożsamościowych Polaków jako obywateli innych państw powstałych po upadku ZSRR, Polaków na Litwie, w Białorusi, w Kazachstanie czy w Buriacji. To, co było oczywiste i jednoznaczne w przeszłości, obecnie staje się często relatywne i niejednoznaczne. Na przykład, przez okres przedrozbiorowy polska świadomość narodowa miała charakter otwarty (Korona i Litwa jako wspólna Ojczyzna Polaków, Białorusinów, Litwinów, Ukraińców, Żydów, Niemców, Łotyszów). Naród był wieloetniczny, a w jego obrębie spotykało się ludzi różnej mowy i wyznania. To swobody ludzkie i obywatelskie, tolerancja religijna i atrakcyjność kultury polskiej sprawiały, że postępowała polonizacja językowa, kulturowa i świadomościowa szlachty niepolskiego pochodzenia. Nie obawiano się obcych wpływów, o czym świadczy między innymi fakt, że polski strój narodowy noszony przez szlachtę - „kontusz” został przyswojony przez Polaków z kultury tureckiej, krzywa szabla - „karabela” z kultury perskiej. Można powiedzieć, że czerpano ze wszystkich stron, przerabiano i dopasowywano do swojej obyczajowości i tradycji. Jeszcze w 1863 roku, podczas powstania styczniowego, godłem tajnego rządu narodowego był trójdzielny herb z wizerunkiem Orła Białego (Polska), Pogoni (Litwa), Archanioła (Ruś). Terytorium Wielkiego Księstwa Litewskiego stanowiło, aż po XX stulecie, swoistą ekumenę kilku narodowości, stąd J. Piłsudski, po wkroczeniu z wojskiem polskim do Wilna w kwietniu 1919 roku, wydał w dwóch językach odezwę „Do mieszkańców byłego Wielkiego Księstwa Litewskiego”. Jednak to my Polacy tak widzimy i szczycimy się złotymi wiekami polskiej tolerancji, inne narody wyraźnie inaczej, jakby w opozycji do nas zaczęły kształtować swoją tożsamość, postrzegając nas jako zagrażających-wrogich w tym procesie, a przecież mamy wspólną spuściznę historyczną i możemy na niej wiele budować. Możemy szczycić się Pawłem Włodkowicem, aktem z 1573 roku konfederacji warszawskiej nadającej wolność religijną w I Rzeczpospolitej czy unią polsko-litewską.

W historii ludzkości kultury ginęły, gdy nie znajdowały w sobie sił, aby absorbować i kształtować Innych swoimi wartościami, ich atrakcyjnością. Może dlatego Litwini uważają, że zawłaszczyliśmy i dalej zawłaszczamy ich kulturowo, że Unia Lubelska to zdrada. Może dlatego ograniczają edukację w języku polskim na Litwie i tolerują hasła i działania nacjonalistyczne i ksenofobiczne Litewskiego Związku Młodzieży Narodowej. Podobne problemy przeżywają Polacy na Białorusi i często formułują trudne tożsamościowo 
pytania, takie jak: co to znaczy być Polakiem na Białorusi, jakie trudności mają przyznający się, deklarujący i zachowujący polskość, czy i jakie trudności powoduje przyznawanie się do wartości rdzennych, czy i kogo się bać, czy mogę pozwolić sobie na niezależność i wolność identyfikacyjną?

$\mathrm{Z}$ jednej strony polityka władz białoruskich jest jasna. Na Białorusi nie ma żadnych Polaków, to produkt natarczywej ideologii polskiej. Są na Białorusi białoruscy Polacy, do których Polska nie ma prawa się wtrącać. Jednakże w kontekście samowiedzy część odpowiada, że dziadowie tu żyli, rodzice tu wyrośli i my się czujemy Polakami, próbując realizować i bronić wartości rdzennych przekazywanych z pokolenia na pokolenie. Część z kolei, mając poczucie odrębności kulturowej, zauważa, że rusyfikacja zrobiła swoje. Mówimy po rosyjsku, gdyż prościej i łatwiej rozmawiać w tym języku. Rezygnujemy z języka polskiego i z działalności na rzecz utrzymania kultury polskiej, aby się nie narażać. „...do czego to potrzebne, żyjąc tu i nie mając nadziei na zmianę"1. Mając pracę, zauważając możliwości awansu, bojąc się o siebie i dzieci, niejednokrotnie rezygnują z prezentowania subiektywnego poczucia odrębności kulturowej. Pozostają jednak pytania: jak kształtowano wartości rdzennej kultury, jak wzrastano w pierwsze wartości, czy utrwalono i nadano im określoną rangę w hierarchii wartości, czy posiadają świadomość identyfikacji z grupą pochodzenia i jednocześnie poczucie obywatelstwa?

W kontekście tych problemów trudno i jednocześnie łatwo zrozumieć list Polaków Grodzieńszczyzny do Prezydenta, Sejmu i Rządu Rzeczypospolitej Polskiej. List podpisało wielu niewymienionych z nazwiska szefów przedsiębiorstw, instytucji, organizacji, uczonych, pedagogów: „Urodziliśmy się i wyrośliśmy na ziemi białoruskiej. Ona stała się dla nas Ojczyzną i domem. Państwo białoruskie dało nam i naszym dzieciom wykształcenie, zrobiło z nas ludzi. Dano nam możliwość zajmowania wysokich stanowisk, bycia deputowanymi. Jesteśmy dumni z tego, że jesteśmy obywatelami Republiki Białoruś".

Czy obywatelstwo nakazuje zostawić wartości rodzime w domu, czy niemożliwa jest jednocześnie lojalność wobec kultury narodowej i zamieszkiwanego kraju?

Może ludzie nie chcą i nie mają wyboru, gdyż muszą tam żyć, są obywatelami Białorusi, mają paszporty, muszą pracować, aby utrzymać rodzinę,

Najczęściej podaje się, że mniejszość polska na Białorusi liczy około 400 tys. Dane kościelne mówią, że jest ponad $1 \mathrm{mln}$ katolików, a generalnie katolik to Polak. Związek Polaków - największa pozarządowa organizacja liczy około 27 tys. członków i utrzymuje się od lat na tym samym poziomie. 
boją się o emerytury, boją się o to, że coś im odbiorą. Zostali tu i są u siebie, założyli rodziny, często mieszane, mają mieszkania, domy, dacze, władza nie chciała ich wypuścić, a w Polsce nikt na nich najczęściej nie czekał. Ażeby obiektywnie być, jak wskazują, to trzeba udokumentować pochodzenie, starać się o drugie obywatelstwo, wnieść opłatę i czekać, jednak najczęściej domowe i kościelne archiwa przepadły. Z drugiej strony liczy się każdy dolar, a czekać nikt nie lubi i nie bardzo wierzy, a więc po co to wszystko najczęściej pytają. Może więc lepiej nie drażnić urzędników państwowych, żyć po bożemu i robić swoje i nie przyznawać się publicznie, podkreślają często w rozmowach. Wówczas nikt nie uciska, nie ma się czego bać, nie ma się problemów, szczególnie wówczas, gdy przestrzega się zasady: w tym kraju trzeba być obowiązkowo zadowolonym.

Chciałbym zauważyć i zwrócić uwagę na inny problem, na to, że zdarzają się i tacy, którzy instrumentalnie traktują przynależność i deklarują tożsamość narodową polską. Deklarują polskość i zgłaszają się po opinie do organizacji chcąc wyjechać na studia, otrzymać stypendium. Są jednak tacy, z pewnością jest ich większość, którzy się identyfikują z polskością, nie oczekując niczego. $Z$ wyboru chcą przyznawać się do dziedzictwa kulturowego przodków, mają świadomość swoich korzeni narodowych, świadomie wybierają, świadomie chcą się różnić od pokolenia rodziców, które dorastało w sowieckiej rzeczywistości i w rosyjskich szkołach straciło często wiodący wyróżnik - język, zachowując tylko tradycyjną religijność. $\mathrm{Z}$ pewnością młodzież jest inna od pokolenia dziadków, ich patriotyzm jest inny, może bardziej pragmatyczny, mniej idealistyczny. W kontekście powyższego istotnym problemem dla Polaków na Wschodzie jest obecnie Karta Polaka. Odżyły frustracje i obwinianie się wśród starszego pokolenia, że nie wyjechali do Polski, a wśród młodszego pokolenia żal do rodziców, że nie podjęli ważnej decyzji w odpowiednim czasie, a oni urodzili się w niewłaściwym kraju. Państwo białoruskie jest państwem zróżnicowanym kulturowo. Wskazuje się na 140 etnicznych wspólnot oraz 26 wyznań [Jewgienij, Babosov, Babosova 2012].

Wielokulturowość jest więc faktem, a postępująca złożoność struktur społecznych, tworzenie wartości konkurencyjnych wobec dominującego porządku, stwarza $\mathrm{z}$ jednej strony zapotrzebowanie na tożsamości lojalne wobec państwa, którego jest się obywatelem, z drugiej strony powstaje potrzeba i konieczność prezentowania wielu lojalności. Jest to także związane z kulturowym oporem wobec zawłaszczania tożsamościowego i z ustawicz- 
ną walką ze strukturami i instytucjami zagrażającymi poczuciu ciągłości tożsamości indywidualnej. Sądzę, że państwa będą powoli ewoluować w kierunku realizacji potrzeb obywateli, a nie interesów członków grup narodowych, czy mniejszości narodowych, eliminować zasady dominacji i podporządkowania na rzecz partnerstwa, upodmiotowienia poszczególnych mniejszości, na rzecz emancypacji. Takie wnioski są między innymi wynikiem wywiadów prowadzonych przeze mnie w 2012 roku wśród Polaków zamieszkujących w Ułan-Ude (Buriacja). Istotą funkcjonowania i rozwoju państw zróżnicowanych kulturowo jest stwarzanie warunków i możliwości do realizacji naturalnych potrzeb utrzymania i budowania więzi narodowych nie tylko narodowi dominującemu, ale także innym grupom etnicznym i religijnym zamieszkującym republikę Buriacji. Przyjmuje się, że osoby, które mogą realizować i wyrażać rdzenne wartości i więzi narodowe, stymulują w efekcie procesy rozwoju całej społeczności, miasta, regionu, republiki.

W Kazachstanie także były takie nadzieje na kreowanie tożsamości jak w Buriacji, jednak w ostatnich latach coraz więcej jest obaw i lęków o utrzymanie i kultywowanie dziedzictwa kulturowego. Świadczy o tym między innymi wypowiedź F. Bogusławskiego, prezesa Związku Polaków w Kazachstanie: „Kazachstan zamieszkują przedstawiciele ponad 100 narodowości. I to państwo według nowej konstytucji ma stać się państwem jednonarodowościowym, z jednym językiem państwowym. Ustawa o komitecie bezpieczeństwa państwowego daje mu niespotykane nigdzie w demokratycznym świecie prawa. Czy jest tu miejsce na demokrację, czy my troszeczkę powstawszy z kolan nie staniemy na nie ponownie, w dodatku pod presją nacjonalizmu? (...) sytuacja jest bardzo poważna, chociaż zewnętrznie w centralnym i północnym Kazachstanie wygląda jakby w porządku. Ale już pojawiają się w prasie artykuły, w których twierdzi się, że jeśli komuś się nie podoba w Kazachstanie, mogą stąd wyjeżdżać" [O Polakach... 1992].

Przedstawiając specyfikę tożsamości kazachstańskich Polaków należy zauważyć proces jej kształtowania poczynając od deportacji poprzez autochtonizację, a w ostatnim okresie możliwość repatriacji do Polski lub akulturacji w kierunku asymilacji w Kazachstanie. Marginalizowanie, brak uznania, a także niszczenie rodzimej tożsamości przez władzę sowiecką, spychanie różnic kulturowych na margines, narzucanie jednego standardu w wyniku prowadzonej polityki kulturalnej i edukacyjnej prowadziło w ZSRR jednoznacznie w kierunku asymilacji. Dążono do wyeliminowania różnic z życia społecznego, nawet ze sfery prywatności i sfery rodzinno-familijnej. Obok działań politycznych standaryzację wspierały 
media i edukacyjne „programowanie” ludności na człowieka radzieckiego, a w ostatnich latach na filozofię "mieć” z ideologią konsumeryzmu, kulturą masową adresowaną do większości, co w efekcie eliminowało, redukowało różnorodność. Najważniejszą i jedynie potrzebną, wskazywaną i uznawaną identyfikacją była identyfikacja państwowo-radziecka. Podobnie dzieje się obecnie w Kazachstanie, jak wskazuje Luba Jakubowska-Malicka. Przywołując zadania wskazane przez Zgromadzenie Narodów Kazachstanu zwraca uwagę, że kształtowanie kazachstańskiej tożsamości ma odbywać się drogą konsolidacji etosów Kazachstanu na podstawie obywatelskiej i duchowokulturowej wspólnoty przy centralnej roli państwowego języka i kultury kazachskiej [Jakubowska 2011].

W Kazachstanie mieszka około 130 narodowości i po rozpadzie ZSRR, od 1990 roku, nastąpiła promocja kultur mniejszościowych, także polskiej. Do Kazachstanu przybyli polscy nauczyciele, do Polski wyjechali pierwsi studenci, z inicjatywy „Wspólnoty Polskiej”, Fundacji „Pomoc Polakom na Wschodzie", ustanowionej w 1992 roku przez Skarb Państwa, w celu współpracy z Polakami, podtrzymywanie polskości, kultury, tradycji narodowych, podejmowano wiele form działalności. W 1995 roku powstało Zgromadzenie Narodów Kazachstanu. W szkołach republiki prowadzono 18 języków mniejszości narodowych. Powstało 178 niedzielnych szkól, w uczelniach powołano wydziały przygotowujące nauczycieli języków etnicznych, organizowano wyjazdy i studia w Polsce, powołano kilkanaście pism etnicznych i kanałów radia, ponad czterdzieści programów telewizyjnych w dwunastu językach itd. Powrót kazachstańskiej Polonii umożliwiła Ustawa $\mathrm{z}$ dnia 9 listopada 2000 r. o repatriacji skierowana do Polaków „którzy pozostali na wschodzie, a zwłaszcza w Azjatyckiej części byłego Związku Socjalistycznych Republik Radzieckich i na skutek deportacji, zesłań i innych prześladowań narodowościowych lub politycznych nie mogli w Polsce nigdzie się osiedlić" [Ustawa 2000] .

Zgodnie z paragrafem 9 wiza wjazdowa w celu repatriacji może być nadana osobie polskiego pochodzenia, która przed wejściem w życie ustawy zamieszkiwała na stałe azjatycką część Federacji Rosyjskiej lub jedną z 8 republik byłego ZSRR. Ustawa o repatriacji z 2000 roku była skierowana wyłącznie do obywateli ZSRR, przy czym była sformułowana $\mathrm{w}$ ten sposób, aby uprzywilejować Polaków z Kazachstanu, ale dyskryminowała Polaków mieszkających w państwach przygranicznych z Polską (Ukraina, Białoruś i Państwa Nadbałtyckie). Te republiki pominięto, gdyż spodziewano się, że mogą stanowić konkurencję dla Polaków z azjatyckiej części ZSRR. Najwięcej chętnych było w 2002 roku, ponad tysiąc osób, następnie 
liczba malała. Przyczynami osiedlania się w Polsce była chęć poprawy sytuacji materialnej i bezrobocie. Gdy sytuacja ekonomiczno-społeczna uległa stabilizacji, zainteresowanie repatriacją zmniejszyło się i można mówić o porażce rządu polskiego w tym zakresie. Skorzystali z niej w pierwszej kolejności animatorzy życia polonijnego, co spowodowało, że społeczność polska na wschodzie została pobawiona elit. Przesiedleńcy przyjechali w latach, gdy wyż demograficzny wchodził na polski rynek pracy, co spowodowało niechęć w przyjmowaniu ich i zatrudnianiu. Ponad połowa repatriantów zamieszkała w województwach mazowieckim, dolnośląskim i małopolskim, zatem migracja nie poprawiła wskaźników demograficznych w województwach wschodnich. Poza tym, zaangażowanie władz lokalnych było niewielkie w pomocy przesiedleńcom, niewspółmierne w stosunku do obietnic i oczekiwań przesiedlających się, stąd proces adaptacji znacznie gorzej przebiegał niż zakładano. Generalnie należy wskazać, że ani jedni, ani drudzy do tego nie byli przygotowani. Najszybciej i najefektywniej adoptowała się młodzież, która studiowała w Polsce. Miała czas na zorientowanie się w polskich realiach i opanowanie języka, a rodziny repatriowane najczęściej nigdy w Polsce nie były i miały poważne problemy językowe. Poza tym doświadczały od Polaków w naszym kraju wiele negatywnego w kontekście funkcjonujących stereotypów i uprzedzeń do języka rosyjskiego, języka symbolizującego zaborcę i władzę sowiecką.

Sądzę, że tożsamość Polaków na Białorusi, Litwie, w Kazachstanie czy w Buriacji, to tożsamość składająca się z syndromu (kompleksu) dopełniających się, czasem sprzecznych, czasem równolegle realizowanych, identyfikacji ze wspólnotami historycznymi i współcześnie występującymi w miejscu ich zamieszkiwania. W efekcie można mówić o dynamicznym, zmiennym, stale dziejącym się procesie tożsamości kulturowej, poczynając od identyfikacji wyznaniowej (katolik, prawosławny), narodowej (Polak, Białorusin, Litwin, Ukrainiec), obywatelskiej (obywatel danego kraju, człowiek radziecki) aż do tożsamości europejskiej.

Najbardziej na Białorusi zauważa się dwoistość narodową (identyfikacja z Białorusinami i z Polakami), co jak sądzę, jest związane z rodzinami mieszanymi i lojalnością wobec narodu dominującego, który z trudnościami rewitalizuje i kształtuje swoją tożsamość narodową, identyfikacją z obywatelstwem białoruskim, emocjonalnymi więziami autochtona zamieszkującymi te ziemie od wieków.

Przedstawiłem, co potwierdzają badania Iwony Kabzińskiej, że tożsamość etniczna i wyznaniowa Polaków na Białorusi jest immanentnie z sobą związana. „Istnieje bowiem bezpośredni związek między tożsamo- 
ścią etniczną (narodową) a religią, która postrzegana jest przez członków tej zbiorowości jako kluczowy wyróżniający grupę element kultury” [Kabzińska 1999: 41]. Jeżeli kościół na Litwie, Białorusi czy Ukrainie jest postrzegany jako instytucja nie tylko zabezpieczająca transmisję religijną, ale także etniczną i kulturową, to już w Kazachstanie i Buriacji nie jest tym „bastionem polskości”. Wspólnotę polską na Białorusi określa się jako białoruskich Polaków, mniejszość polską czy Polakami kościelnymi. Samoidentyfikacja członków do wspólnoty polskiej ma różne podstawy (polskie korzenie, identyfikacja z kulturą, przynależność wyznaniowa (rzymskokatolicka), rodziny mieszane). Obecnie zauważa się zmniejszenie wagi języka polskiego jako czynnika przynależności grupowej. W tym przypadku szczególnym problemem są granice wyrażania i manifestowania na zewnątrz kulturowej odrębności. W sytuacji skupienia wielu grup, w Kazachstanie czy Buriacji, na wspólnym terytorium, ich przedstawiciele, w dużej mierze pozbawieni języka ojczystego, nauczyli się także ograniczać niektóre tradycje, aby niwelować groźbę antagonizmów i konfliktów. Nauczyli się pokory wobec prawa, którego w rodzinach nie przestrzegano. Można powiedzieć, że próbowali stworzyć atmosferę zgodnej koegzystencji różnorodnych kultur, realizując narzuconą przez władze tożsamość radziecką. W wielu przypadkach nie chodziło o rezygnację $\mathrm{z}$ własnych wartości, ale o zewnętrzne podporządkowanie się regułom ustanowionym przez większość narodową i państwo. W Ułan-Ude podczas prowadzonych wywiadów często wskazywano, że jest w naszej republice tak wiele narodowości, że winniśmy się powstrzymywać od naruszania uprawnień innych, nie narzucać im własnego zdania, negocjować zachowania, unikać konfliktów, dbać w pierwszej kolejności o lojalność wobec państwa, gdyż to jest gwarantem stabilności, a nie o nacjonalistyczne interesy wspólnoty mniejszościowej.

Uważam, że koncepcja transkulturowości w edukacji międzykulturowej umożliwi i pozwoli zrezygnować z tradycyjnego obrazu świata i trwałych podziałów kulturowych. Transkulturowość proponuje dynamiczny proces: płynność, mieszanie się, kontakty, ustawiczne interakcje, zacieranie się granic między kulturami. Odzwierciedleniem sposobu istnienia kultury jest jednostka autotranscendentna, dynamicznie kształtująca własną toż- 
samość. W tym kontekście żywe więzi z krajem pochodzenia nie muszą wpływać negatywnie na proces inkluzji i integracji. Zwolennicy transnarodowego podejścia przekonują, że dzieje się dokładnie odwrotnie: transnarodowe więzy i powstające dzięki nim przestrzenie sprzyjają procesowi adaptacji migrantów do nowej rzeczywistości, co mogłem obserwować i doświadczać już wiele lat temu podczas pobytu w Kanadzie. Transnarodowość stanowi bowiem jeden z przejawów globalizacji. Odnosi się do wielorakich powiązań i interakcji, które ponad granicami państw narodowych łączą ludzi oraz instytucje [Vertovec 2012]. W transnarodowych przestrzeniach migranci tworzą więzi społeczne, kulturowe, polityczne i ekonomiczne. Jednym $\mathrm{z}$ wymiarów transnarodowości jest kultura, w obrębie której zachodzi proces kulturowej interpretacji i kulturowego łączenia różnych elementów. Nowi Europejczycy, czerpiąc nie tylko z jednej spuścizny, często świadomie selekcjonują i synkretyzują różne aspekty kultury i tożsamości [Kindler 2008: 55]. Thomas Faist [2006] wskazuje, że synkretyzm pozwala na współistnienie kultury dominującej z różnymi kulturami etnicznymi, a nawet subkulturami powstałymi na ich granicach. Tak też traktujemy wiele działań z zakresu edukacji międzykulturowej, realizując niniejszą koncepcję jako istotną i atrakcyjną ze względu na proponowane rozumienie kultury. Nie jest to już stała i określona na zawsze zawartość pojemnika pod nazwą kultura i tożsamość, co sugerują koncepcje asymilacji i pluralizmu, lecz zmieniająca się ilościowo i jakościowo zawartość, trudna do określenia i przewidzenia. Nowatorstwo tej koncepcji polega na porzuceniu idei wyrazistej tożsamości kulturowej i instrumentalnym potraktowaniu kultury jako narzędzia adaptacji. Kulturowe znaczenia, symbole i zwyczaje podlegają procesom przemieszczania się i zmiany, tak samo jak migrujący ludzie. Faist nie rezygnuje z pojęcia wielokulturowości, lecz czyni je warunkiem transnarodowości. „Poprzez społeczne i symboliczne więzi następuje wymiana znaczeń pomiędzy dwu i więcej społeczeństwami oraz dochodzi do syntezy starych i nowych wzorców" [Kindler 2008: 55]. Transmigranci gromadzą w ten sposób kapitał społeczny i kulturowy przydatny w procesie integracji. Problemem metodologicznym jest więc obejmowanie wielu zakresów kultury i kształtowanej w niej i przez nią tożsamości, poczynając od kultury lokalnej i narodowej, opartej na języku, historii, wzorcach osobowych, zasadach i wartościach przekazywanych pokoleniowo, poprzez kulturę państwową, obywatelską do kontynentalnej i planetarnej. 


\section{Bibliografia}

Andruchowicz J. (2005), Ukraińska apologetyka, [w:] Sny o Europie, wybór i red. O. Hnatiuk, przeł. O. Hnatiuk, K. Kotyńska, R. Rusnak, Kraków.

Beck U. (2007), Unia nie jest tylko dla elit, „Gazeta Wyborcza”, z 22 czerwca.

Dunajeva V. (2012), W poszukiwaniu idei narodowej; nacjonalizm we współczesnej Rosji, [w:] M. Biernacka, K. Krzysztofek, A. Sadowski (red.), Społeczeństwo wielokulturowe nowe wyzwania i zagrożenia, Białystok.

Faist T. (2006), The Transnational Social Spaces of Migration, Bielefeld, Working Paper 10. Centre on Migration. Citizenship and Development.

Jakubowska L. (2011), Tożsamość kulturowa Polaków z Kazachstanu w kontekście tendencji globalizacyjnych, Legnica.

Jewgienij M., Babosov S., Babosova J. (2012), Rola kultury narodowej w przestrzeni wielokulturowości, [w:] M. Biernacka, K. Krzysztofek, A. Sadowski (red.), Społeczeństwo wielokulturowe - nowe wyzwania i zagrozenia, Białystok.

Kabzińska I. (1999), Wśród „kościelnych Polaków”; wyznaczniki tożsamości etnicznej (narodowej) Polaków na Białorusi, Warszawa.

Kindler M. (2008), Transnarodowość. Nowe teorie migracyjne a wyzwania integracji imigrantów, [w:] A. Grzymała-Kazłowska, S. Łoziński (red.), Problemy integracji imigrantów. Koncepcje, badania, polityki, Warszawa.

Nikitorowicz J. (2000), Młodzież pogranicza kulturowego Polski, Białorusi i Ukrainy wobec integracji europejskiej. Tożsamość, plany życiowe, wartości, Białystok.

O Polakach z Kazachstanu. Wystąpienie F. Bogusławskiego, prezesa Stowarzyszenia na Zjeździe Polonii Świata w Krakowie, Kraków 1992, [w:] F. Bogusławski (2005), Z kazachstańskich stepów do Sejmu RP, Warszawa.

Skarga B. (1997), Tożsamość i różnica. Eseje metafizyczne, Kraków.

Ustawa z dnia 9 listopada 200 r. o repatriacji, Dz. U. z 2004 r., nr 53, poz. 532.

Vertovec S. (2012), Transnarodowość, przeł. I. Kołban, Kraków.

Włodek L. (2014), Wystarczy przejść przez rzekę, Azja Środkowa: Kirgistan, Tadżykistan, Turkmenistan, Kazachstan, Uzbekistan, Kraków. 


\section{SUMMARY}

\section{Identity problems of the nationals of the countries formed after the collapse of the Soviet Union}

The author, referring to his own research on the Polish-Lithuanian, Polish-Belarusian and Polish-Ukrainian borderland, formulates the thesis that after the collapse of the USSR individual nations began to develop their own national identity in opposition to other nations.

The author poses the question of the civic loyalty with simultaneous loyalty to the culture of origin, national culture. He gives examples and attempts to answer in the context of the arising problems of identity in the emerging multicultural societies. Particular attention is paid to the problems of identity of Poles, as citizens of other countries created after the collapse of the Soviet Union, that is of Poles in Lithuania, Belarus, Kazakhstan, Buryatia.

KEYWORDS: culture, multiculturalism, transculturalism, identity, intercultural education 